\title{
Development of Community-Based Tourism in Kampung Adat Takpala, Alor, Indonesia
}

\author{
Feny Susana Eky ${ }^{1}$, Rulli Saragi ${ }^{1}$, Christina M. Mantolas ${ }^{1}$, Oktovianus Lanata ${ }^{1}$ \\ (nyeky_fe@yahoo.com; rullisaragi@yahoo.com; mantolaschristina@gmail.com, \\ ocky_lanata@yahoo.com) \\ Politeknik Negeri Kupang ${ }^{1}$
}

\begin{abstract}
Kampung Adat Takpala is one of the traditional villages that offers culture as a tourism potential. The tourism potential has not been well utilized by the Takpala community in increasing their growth. This is caused by weakness. For this reason, a community-based development strategy is needed. The purpose of this study was to determine the tourism potentials of the Takpala Traditional Village and also to find the development strategies that can be used in the Traditional Village of Takpala. In this study the method used is a descriptive qualitative method with direct observation and interviews of approved informants such as the Chief of the Takpala Customs, Village Heads, Community Leaders and the District Tourism Office Alor. Based on the results of the analysis using SWOT analysis techniques, it shows the existence of a new development strategy that can be used to build the Takpala Customary Village and to improve the quality of community human resources by using the principles of Community Based Tourism.
\end{abstract}

Key words: Community-Based Tourism, Kampung Adat Takpala

\section{Introduction}

Alor is an island district that is rich in natural and cultural attractions. Besides underwater attractions that are interesting to visit, Alor is also famous for cultural tourism. One of Alor's cultural attractions that stands out is the Takpala Traditional Village. Kampung Adat Takpala is a traditional village on a hill that is not so far from the coast. The location is in Desa Lembur Barat, Alor Tengah Utara District, Alor Regency. As a traditional village, Takpala has 14 well-organized traditional thatch-roofed pyramid houses that are inhabited by 13 families.

Kampung Adat Takpala sticks out in the list of tourist arrivals from Europe after a Dutch tourist named Ferry exhibited photographs of 1973 Takpala villagers. He took a photo of Kampung Adat Takpala for a calendar and promoted that on Alor Island there was a primitive village. Since then, Kampung Adat Takpala has been known by Europeans and tourists have come to this village. In addition, in 1980 Kampung Adat Takpala was also selected as the 2nd place winner at the National level in the most traditional village category. Since 1983, the Takpala Traditional Village has been designated as one of the tourist destinations on Alor Island by the Alor Tourism Office. According to data from the Alor Regency Tourism Office, every year the number of tourist visits to Kampung Adat Takpala continues to increase. According to data received, in 2018 there were 2,126 tourists both (domestic and foreign).

The development of tourism in Kampung Adat Takpala, takes the participation of the community in developing the cultural potential that exists in Kampung Adat Takpala; such as 
weaving traditional clothes and various souvenirs produced by the Takpala women, there are also Lego-lego and Cakalele dances, traditional rituals such as the toll-typhoid ritual (land clearing ceremony) which is preceded by labor ceremonies. The anticipated benefits of CBT are three; 1) CBT generates income and employment and, contributes to rural development, a benefit that especially applies in remote areas. 2) The benefits derived from the use of natural resources for tourism will prompt the community to use these valuable resources in a sustainable way; and 3) CBT adds value to the national tourism product through diversification of tourism, increasing volume and economies of scale [1]. The community is required to play an active role in developing existing potentials and being able to package these potentials into cultural attractions that can be sold to tourists. It is also able to preserve and maintain the unique culture and environment of Kampung Adat Takpala. With the aim of increasing the number of tourist visits, Kampung Adat Takpala can become a cultural tourism destination which can also increase the income of the people in Kampung Adat Takpala.

So far, the community of Kampung Adat Takpal has not actively involved in developing tourist attractions in the Takpala Indigenous village. Lack of knowledge about tourism, especially tourism products, makes them more hopeful of the local government. As the executor or subject of tourism in Kampung Adat Takpala, the local community has not played an active role in the development of tourism in Kampung Adat Takpala and its surroundings. This condition is quite alarming because the cultural potential that exists in Kampung Adat Takpala is so valuable both in terms of aesthetics and uniqueness, which has not been managed optimally. This is more due to the condition of the people who do not fully understand the importance of tourism in improving their economy. In addition, there is also a lack of development direction and strategy for developing community-based tourism activities. Community-based tourism development strategies prioritize the development of 5 dimensions namely; economic dimensions, social dimensions, cultural dimensions, and environmental dimensions [2].

\section{Research Methods}

This research uses qualitative descriptive analysis [3] and then analyzed further with SWOT (strengths, weaknesses, opportunities and threats) that are used to prepare community development planning in Kampung Adat Takpala. SWOT analysis is used to learn about the description and development of community-based leading in Kampung Adat Takpala and the opportunities and costs required.

\subsection{Research Stages}

Both external and internal data were carried out by interviewing several key informants, namely community leaders of the Takpala Customary Village, the Head of the West Lembur Village, the Head of the Alor Regency Tourism Office Destination Development. There is also data in the form of documentation on the website, thesis or other scientific writing about Kampung Adat Takpala. In addition, direct observation was made of Kampung Adat Takpala, Alor Regency.

\section{Data Collection}


After the data is collected and concluded then it is analyzed using a SWOT analysis tool. SWOT analysis is one of the tools in strategy management to determine the strengths, weaknesses, opportunities and threats in the organization. SWOT analysis is required in developing organizational strategies in order to achieve goals effectively and efficiently. The SWOT Matrix can clearly describe how external opportunities and threats faced by a company can be adjusted according to its strengths and weaknesses [4].

\section{Result and Discussion}

\subsection{Result}

This research uses descriptive analysis and then analyzed further with the SWOT (strength, weakness, opportunity and threat) approach which is used to prepare communitybased tourism development planning in the Takpala Traditional Village. The SWOT analysis is intended to find a picture of the strengths and weaknesses of the development of Communitybased Tourism in the Takpala Traditional Village and the opportunities and threats they face. I. Internal Factors (Strengths and Weaknesses)

In planning a community-based tourism development strategy (CBT), in the Takpala Traditional Village, the writer analyzes the strengths and weaknesses internally.

A. Strength

1) Cultural traditions that exists

Kampung Adat Takpala is one of the most famous traditional villages in Alor Regency. This is in accordance with the authenticity and uniqueness of culture that is still maintained such as the farming ceremony (Tifol Tol ritual) which is unique, where the ritual begins by slaughtering the hunted animals and continuing Lego-lego together, after Lego-lego, the traditional elders will start the ritual, and after a series of ceremonies have been completed the community is then put into the garden.

According to the Chairman of Kampung Adat Takpala, Seprianus Hiyetingkai, "Tifol Tol ritual is a tourist attraction that most tourists want to see especially foreign tourists". This was justified by Melkiur Fanata as the Head of Desa Lembur Barat, he said that "in June many foreign tourists came to Kampung Adat Takpala because it was in June that the Tifol Tol ceremony was held". 2) Cakalele dan Lego-lego dances

The abui tribe is the largest tribe in Alor district, the Abui tribe itself has a unique dance that is the Caka Lele and Lego-lego dances. Both of these dances have now also become typical dances of Alor Regency. Caka lele dance is a war dance dedicated to the king. This dance is performed when going to war and finished fighting. The Caka Lele dance is usually played by two men who swing each other over a slew or machete while following the drumming played. 


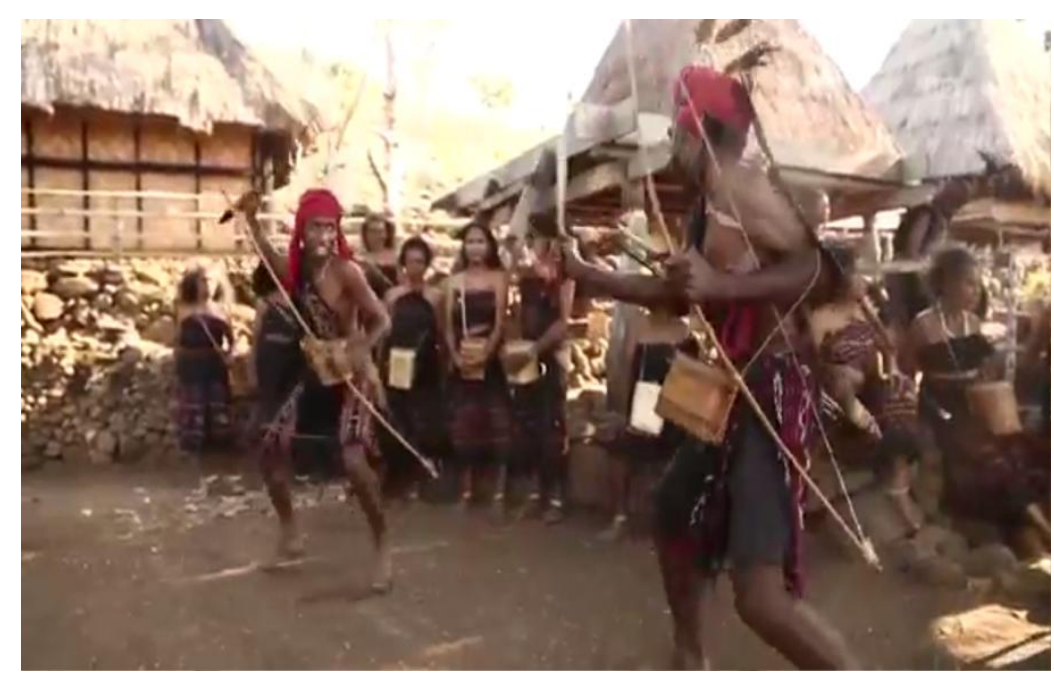

Figure 1. Caka Lele Dance

While the Lego-lego dance is a unity dance symbolizing prostration of gratitude to the ancestors. The Lego-lego dance can be performed by at least 25 people, this dance can be performed in large numbers. But over time these dances are rarely performed, but in the Kampung Adat Takpala this dance is still performed routinely.

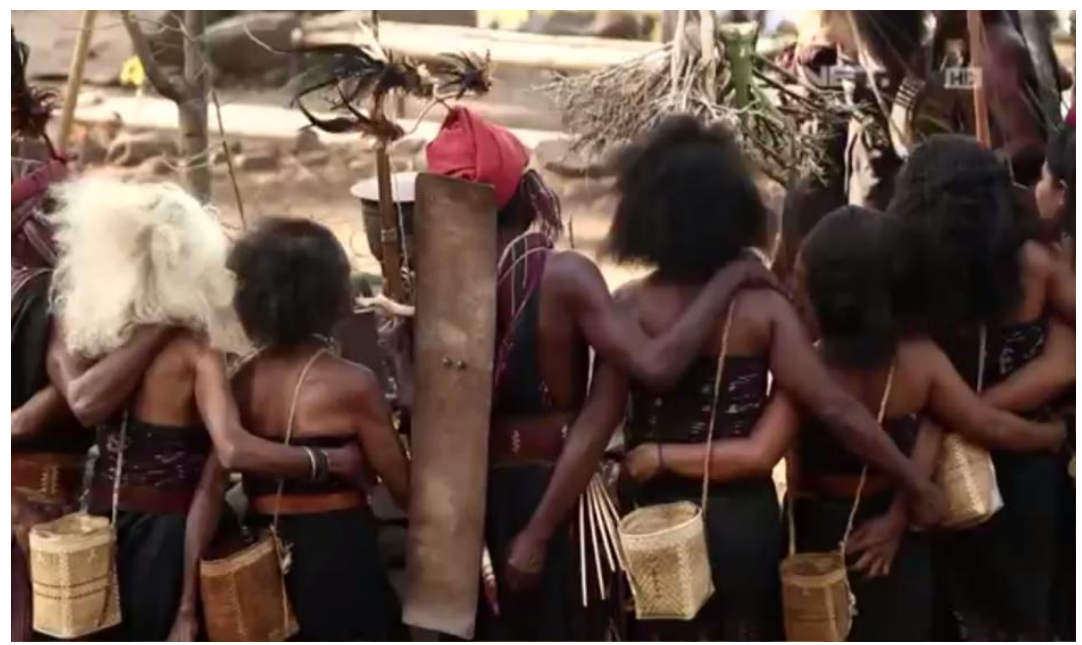

Figure 2. Lego-lego Dance

According to Melkiur Fanata, "The Caka Lele dance is a typical Abui dance, but currently the Caka Lele dance is rarely performed" while according to Seprianus Fanata, "The Lego-lego dance performed at Takpala is different from the Lego-lego in general because it is performed accompanied by the gong and sang mars or special hymns that have been approved ". 
3) Traditional four-storey house

Takpala has 14 traditional pyramid-shaped houses that are neatly arranged. The building of the house is completely untouched by modern materials. This building is said to be unique because it has four levels with different functions. The first level is a meeting place or living room, the second floor is a place to cook and a bed, the third floor is a storage place for garden products such as rice and corn while the fourth floor is for storing valuables such as Moko (Nekara bronzes are pre-historic cultural objects. Now Moko is a dowry used when proposing to a woman from Alor), and other heirlooms..

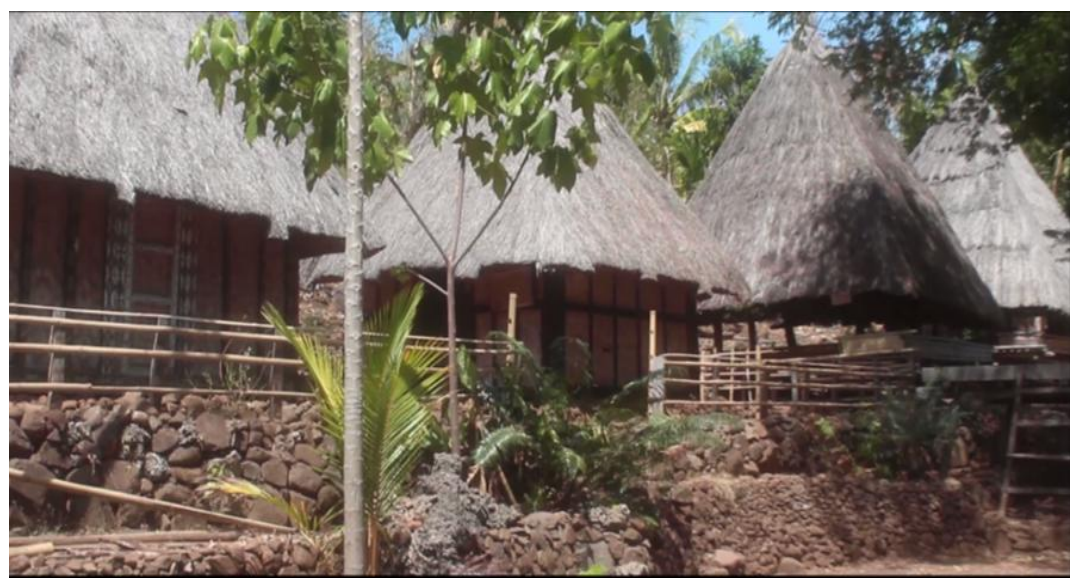

Figure 3. Traditional four-storey house

Seprianus Hiyetingkai emphasized that, "Our traditional house is a very unique house and very difficult to find elsewhere". This opinion is justified by Jhon M. Yetimau as a community leader, "Our traditional house is a unique house because it does not use cement and modern building materials but is a four storey with different level functions."

4) Tradition of hunting.

One of the activities of the Abui community is hunting. Hunting is usually done by men but it differs from the Takpala Traditional Village where not only men hunt but women also hunt. Game animals usual to Takpala people are pigs and deer. The Kampung Adat Takpala men served as archers of prey while the women involved in hunting served the guide dogs. The best hunting season is during the open season, from June to November.

According to Seprianus Hiyetingkai, "Takpala women do not have the duty of archery, but the Takapala women have the duty to move the dog in tracking down prey".

5) The Beauty of Natural Panorama

Kampung Adat Takpala is a traditional village on a hill but at the same time not so far from the coast. This clearly adds to the charm and beauty of the Takpala traditional village. In addition, Kampung Adat Takpala is also arranged well. Arrangement of stone in the yard of the traditional house also adds to its charm and is worth seeing. 


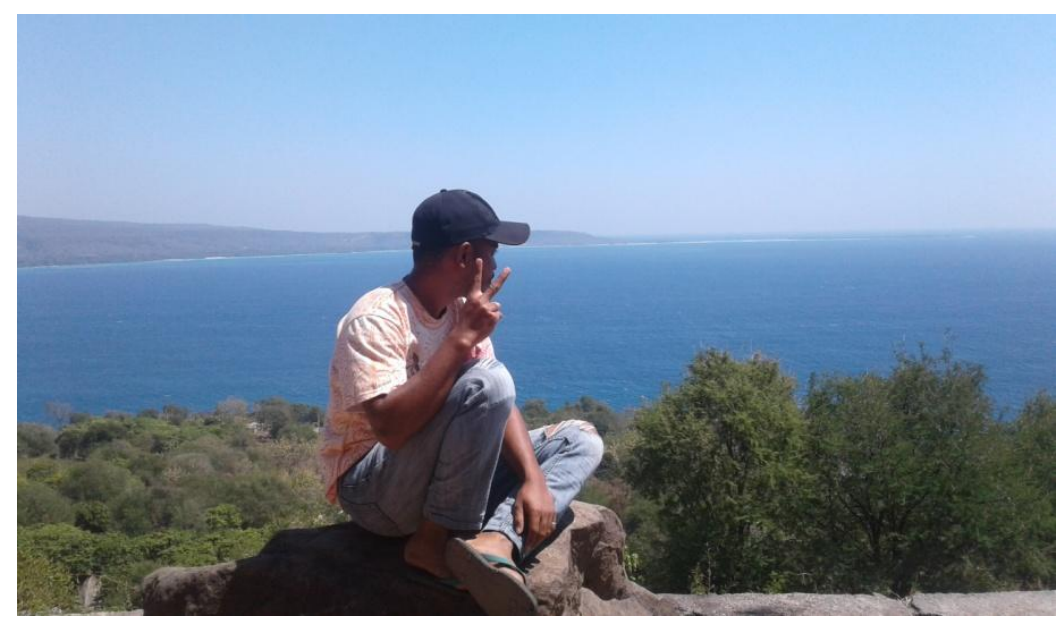

Picture 4. The beauty of the natural panorama of Kampung Adat Takpala

6) Friendliness of the local community

Takpala community is a friendly community with visitors who come to their place. Sometimes tourists who come to visit in the morning and evening will be served coffee as a typical Takpala (Abui) beverage. According to Seprianus Hiyetingkai, "We have to maintain the tradition of Abui where we have to give drinks to people who come to visit our house even though only empty water is a form of our welcome towards visiting guests".

7) Easily Accessed

The traditional village of Takpala is one of the traditional villages that young people visit because it is not so far from the capital city of Kalabahi. Besides that, Kampung Adat Takpala is also easy to reach by public and private vehicles. According to the Head of the Development Section of the Tourism Office of Alor Regency, "Kampung Adat Takpala is very easy to reach because it is not far from the center of the City of Kalabahi and there is also a level road, just entering the village we travel up a little incline but not difficult because of good road access".

II. Weakness

In addition to having strengths as a potential, the Takpala Traditional Village also has weaknesses like this.

1) Weak Human Resources (HR)

The people of the Takpala Traditional Village community generally do not understand community-based tourism. There are some members of the Takpala Indigenous Village community who are still selfish and want to develop themselves by not accepting the West Lembur Village people who are in the lowlands (below) to sell in the Takpala Indigenous Village. This is done by blocking access to the main road (from below) to the Takpala Traditional Village. This incident was terminated by Jack Adang, Head of the Development of Destinations at the Alor Regency Tourism Office, "In July, the head of Lembur Barat Village and I solved a problem of land case in Lembur Barat Village, because there were some members of the Kampung Adat Takpal community who did not want the people from Lembur Barat selling in Kampung Adat Takpala, so they closed access to Kampung Adat Takpala. People do not understand foreign languages, making it difficult for people to communicate with foreign tourists. According to Seprianus Hiyetingkai, "We are still weak in human resources. This is seen when foreign tourists visit and we have difficulty communicating." 
Another thing conveyed by the head of Lembur Barat Village, "The people of Takpala do not understand good financial management, because we don't have good human resources."

2) Lack of facilities

Facilities certainly support all tourism activities in the Kampung Adat Takpala, but there are still many shortages of facilities owned by Kampung Adat Takpala such as the provision of home stays, information boards and rubbish bins that can make tourism activities less stable. According to the head of the village Lembur Barat, "The Takpala people always ask to provide a home stay through village funds, but until now it has not been given".

3) Lack of community creativity.

In taking advantage of the existence of this traditional village as a source of community economic income, people lack creativity in reading business opportunities. This is evidenced by the lack of kiosks, local snacks and traditional weaving. This was justified by the leader of Desa Lembur Barat. "The Takpala people only focus on souvenirs without seeing other opportunities such as local hawker stalls". The head of the Takpala custom said that, "Our lack of creativity makes us still import goods from outside as it does traditional clothes".

Table 1. SWOT Strategy Analysis

\begin{tabular}{|c|c|c|c|c|}
\hline \multirow[t]{8}{*}{ INTERNAL } & \multicolumn{2}{|r|}{ Strengths } & \multicolumn{2}{|r|}{ Weaknesses } \\
\hline & S1 & $\begin{array}{l}\text { Cultural tradition that is } \\
\text { still preserved }\end{array}$ & W1 & Weak human resources \\
\hline & $\mathrm{S} 2$ & $\begin{array}{l}\text { Cakalele and Lego-lego } \\
\text { dances }\end{array}$ & W2 & Lack of facilities \\
\hline & S3 & $\begin{array}{l}\text { Traditional four-story } \\
\text { house }\end{array}$ & W3 & $\begin{array}{l}\text { Lack of local community } \\
\text { creativities }\end{array}$ \\
\hline & S4 & Hunting tradition & & \\
\hline & S5 & $\begin{array}{l}\text { The Beauty of Natural } \\
\text { Panorama }\end{array}$ & & \\
\hline & S6 & Friendly local community & & \\
\hline & S7 & Easily to access & & \\
\hline \multicolumn{5}{|l|}{ EXTERNAL } \\
\hline Opportunities & & Strategy SO & & Strategy WO \\
\hline
\end{tabular}




\begin{tabular}{|c|c|c|c|c|c|}
\hline 01 & $\begin{array}{l}\text { The } \\
\text { developmen } \\
\text { t of tourism } \\
\text { sector }\end{array}$ & S1-01 & $\begin{array}{l}\text { Enhance } \\
\text { preservation of local } \\
\text { cultural traditions }\end{array}$ & W1-01 & $\begin{array}{l}\text { Increase human } \\
\text { resources by } \\
\text { socializations and } \\
\text { trainings such as tour } \\
\text { guiding, English, } \\
\text { business marketing, } \\
\text { etc. }\end{array}$ \\
\hline 02 & $\begin{array}{l}\text { Creating } \\
\text { employment } \\
\text { opportunities for } \\
\text { local people }\end{array}$ & S2-02 & $\begin{array}{l}\text { Increasing } \\
\text { availability of } \\
\text { tourism products to } \\
\text { create new jobs for } \\
\text { local community } \\
\text { such as dances, } \\
\text { souvenirs, typical } \\
\text { local snacks to } \\
\text { attract tourists }\end{array}$ & W2-02 & $\begin{array}{l}\text { Improve facilities to } \\
\text { take advantage of } \\
\text { business } \\
\text { opportunities for } \\
\text { creating new jobs }\end{array}$ \\
\hline 03 & Networking & S3-03 & $\begin{array}{l}\text { Create partnership } \\
\text { with related parties } \\
\text { in supporting the } \\
\text { preservation of } \\
\text { tourism potential of } \\
\text { traditional four- } \\
\text { story houses }\end{array}$ & W3-03 & $\begin{array}{l}\text { Increase networking } \\
\text { with related parties } \\
\text { so that they can } \\
\text { provide socializations } \\
\text { and trainings in } \\
\text { improving } \\
\text { community creativity }\end{array}$ \\
\hline 04 & $\begin{array}{l}\text { Konstelasi } \\
\text { dengan objek } \\
\text { wisata lain }\end{array}$ & S4-04 & $\begin{array}{l}\text { Providing tour } \\
\text { packages that can } \\
\text { attract the interest of } \\
\text { tourists }\end{array}$ & & \\
\hline 05 & $\begin{array}{l}\text { The } \\
\text { development of } \\
\text { information } \\
\text { technology }\end{array}$ & S5-05 & $\begin{array}{l}\text { Increase the } \\
\text { participation and the } \\
\text { role of local } \\
\text { community in } \\
\text { maintaining and } \\
\text { persevering and } \\
\text { introducing the } \\
\text { beauty of natural } \\
\text { panorama }\end{array}$ & & \\
\hline 06 & $\begin{array}{l}\text { Human Resource } \\
\text { Development in } \\
\text { the local } \\
\text { community }\end{array}$ & S6-06 & $\begin{array}{l}\text { Increase community } \\
\text { hospitality in } \\
\text { supporting local } \\
\text { human resources } \\
\text { development }\end{array}$ & & \\
\hline \multicolumn{2}{|r|}{ Threats } & \multicolumn{2}{|r|}{ Strategy ST } & \multicolumn{2}{|r|}{ Strategy WT } \\
\hline $\mathrm{T} 1$ & $\begin{array}{l}\text { Foreign cultural } \\
\text { influences }\end{array}$ & S1-T1 & $\begin{array}{l}\text { Maintain tradition } \\
\text { and culture so as not } \\
\text { to be influenced by } \\
\text { foreign cultures }\end{array}$ & W1-T1 & $\begin{array}{l}\text { Improve human } \\
\text { resources so that } \\
\text { young people are not } \\
\text { affected by foreign } \\
\text { cultures }\end{array}$ \\
\hline $\mathrm{T} 2$ & $\begin{array}{l}\text { Highly } \\
\text { competition }\end{array}$ & S2-T2 & $\begin{array}{l}\text { Preserve Cakalele } \\
\text { dance as tourist } \\
\text { attraction }\end{array}$ & S2-T2 & $\begin{array}{l}\text { Improve the human } \\
\text { resources for local }\end{array}$ \\
\hline
\end{tabular}




\begin{tabular}{|l|l|l|l|l|l|}
\hline & $\begin{array}{l}\text { between the } \\
\text { attractive objects }\end{array}$ & $\begin{array}{l}\text { community } \\
\text { creativities }\end{array}$ \\
\hline T3 & Political & S3-T3 & $\begin{array}{l}\text { Maintain, preserve } \\
\text { and explore culture } \\
\text { to unite the nation }\end{array}$ & W3-T3 & $\begin{array}{l}\text { Increase creativity to } \\
\text { improve economic } \\
\text { income of local } \\
\text { community }\end{array}$ \\
\hline T4 & Natural disasters & S4-T4 & $\begin{array}{l}\text { Improve the } \\
\text { tradition to preserve } \\
\text { nature }\end{array}$ & & \\
\hline
\end{tabular}

\subsection{Discussion}

Based on the SWOT analysis above, it can be seen that Kampung Adat Takpala has the potential to develop into a leading tourist attraction by developing community-based tourism (CBT). Strategies as carried out;

a. SO Strategy

Increasing the preservation of local cultural traditions, increasing the availability of tourism products to create new jobs for local communities such as dances, souvenir businesses, selling local snacks to attract tourist visits, building partnerships with relevant parties in supporting the preservation of traditional four-story home tourism potentials, provide tour packages that can attract the interest of tourist visits, increase participation and the role of the community in maintaining and preserving the beauty of the natural panorama that is owned and introducing the panorama and increasing the hospitality of the people in supporting the enhancement of the human resources of the local community.

b. WO Strategy

Increase human resources by conducting socialization or education about community-based tourism. Giving an understanding of the importance of mutual support as a community that lives in a social environment with a culture that has a high attractive value. Provide training such as English, business opportunities and so on, improve facilities to take advantage of existing business opportunities to create new jobs and increase cooperation with related parties in order to provide socialization and training in increasing community creativity.

\section{c. ST Strategy}

Keeping tradition and culture from being influenced by foreign cultures, preserving Cakalele dance as a tourist attraction in attracting tourist visits, preserving and using culture to unite the nation and increasing tradition to preserve and preserve nature.

d. WT Strategy

There needs to be an increase in community human resources so that young people are not affected by a developing foreign culture, with an increase in human resources the creativity of the community will increase their economic income.

\section{Conclusion and Suggestion}

\subsection{Conclusion}

From the analysis of Community-Based Tourism Development Strategy in Kampung Adat Takpala using a SWOT analysis the lack of human resources (HR) is an important thing that needs attention. Thus it is necessary to have good cooperation between the government, business people and tourism managers in improving the human resources of the Takpala community. 
Thus it can be seen that Kampung Adat Takpala has the strength and opportunity to develop optimally towards a better direction.

\subsection{Suggestion}

From the results of this paper the suggestions that can be conveyed by the author are as follows 1) The community is expected to maintain the authenticity of the local culture by preservation so that tourists get something that can be shared with friends and relatives that in Takpala there is something different, which is not in other places and only found in Takpala.

2) Involving local communities in the process of developing community-based tourism by organizing businesses that address the needs of tourists when conducting tourism activities and optimizing skills coaching, training, and counseling to the community aimed at building tourism awareness for the community.

\section{Referrence}

[1] Salazar, N,B. Community-based cultural tourism : issues, threats and opportunities. (2012). [2] Suansri, Potjana. Community Based Tourism Handbook. Thailand: REST Project. (2003).

[3] Moleong, Lexy J. "Metodologi Penelitian Kualitatif". Bandung: Remaja Rosdakarya. (2010).

[4] Rangkuti, Freddy. Analisis SWOT Teknik Membedah Kasus Bisnis. Jakarta: PT. Gramedia Pustaka Utama. (2006). 